\title{
Sale of surplus land and property
}

The Public Policy Committee has been in correspondence with the Department of Health regarding government rules for the sale of surplus NHS land and property and considers that it will be helpful for members to be aware of government policy.

This is stated in Dr J. Reed's letter as follows:

Dr A. R. M. Freeman

Secretary

Public Policy Committee

Royal College of Psychiatrists

17 Belgrave Square

London SWIX 8PG

Dear Roger

Government Response to the 11th Report from Social Services Committee 1989-1990

Thank you for your letter of 27 August about recommendation 4 of the Eleventh Report of the Social Services Committee 1989-1990 'Community Care: Services for People with a Mental Illness or a Mental Handicap'. As you will know, the position about the use of proceeds from the sale of surplus NHS land and property is set out in paragraphs 4.10 and 4.11 of Part 1 of Property Transactions in the NHS. The observance of the principles set out in this is mandatory on health authorities. Regarding hospitals for mentally ill or mentally handicapped people, the general requirement is that capital proceeds should be specifically used for development of services for the client group concerned unless there are very exceptional circumstances and the Department of Health has agreed to alternative use. The Department has no evidence to suggest that health authorities are not following this instruction.

Yours sincerely

Dr John Reed

Senior Principal Medical Officer

Mental Health, The Elderly and Disabled Division

Room 317, Wellington House, 133-135 Waterloo Road, London SE1 8UG
If members have evidence to suggest that these guidelines are not being followed it is suggested that they notify the Department of Health and the College. In so doing, members should bear in mind that the proceeds referred to are capital funds and that revenue monies are not protected in the same way.

Dr A. R. M. FreEMAN

Secretary

Public Policy Committee

\section{Extracts from Property Transactions in the NHS}

\section{Use of Proceeds from Sales}

4.10 General. In order to encourage DHAs to identify surplus property it is Ministers' policy that DHAs should benefit from the proceeds of sales. RHAs must therefore pass a significant proportion of the sale proceeds to initiating DHAs, within a time-scale which is compatible with agreed strategies, unless the sale results from the provision of a new capital funded facility in which case the RHA may first recoup their capital outlay. This policy will be reviewed on the introduction of capital charging.

4.11 Hospitals for the Mentally Ill and Mentally Handicapped. The general principles of paragraph 4.10 should apply, but in the case of the larger hospitals Ministers have made clear that closure must be preceded by the building up of comprehensive alternative services covering the whole of the hospital's catchment area - which may cover more than one District. This will often have necessitated the provision of capital funded facilities to varying extents over many years. In these cases the RHA should use its discretion as to which Districts should benefit from the sale proceeds - within the general requirement that proceeds should be specifically used for development of services for the client group concerned unless there are very exceptional circumstances and the Department has agreed otherwise.

\section{Erratum}

Election and introduction of Honorary Fellows at the Annual Meeting, 1991 (Psychiatric Bulletin, 15, 782-783). We regret that it was incorrectly stated that Dr J. L. T. Birley's citation was given by Professor Robert Bluglass when in fact it was given by Professor Alwyn Lishman. 